\begin{tabular}{|c|ccc|c|}
\hline & PORT SAID ENGINEERING RESEARCH JOURNAL \\
\hline
\end{tabular}

\title{
Strength properties of Port Said soft clay stabilized by different binders
}

\author{
K. Sharoubim ${ }^{1}$ M. El Gendy ${ }^{2}$ A. Elsherify ${ }^{3}$
}

\begin{abstract}
Due to the short history of the Deep Mixing Method (DMM) in Egyptthere is limited data on the improved properties of Port Said clay. In addition, there are enormous amounts of by-products from cement, marble and limestone industries that need to be employed instead of being environmentally harmful materials. This paper aims to bridge the gap of limited data about the effectiveness of dry mixing method to improve strength properties of Port Saidclay using common binders, cement and lime. In addition, the effectiveness of using cement waste, limestone waste and marble powder to partially or fully replace cement and lime in the dry mixing method was examined.To achieve this purpose, a large number of unconfined compression testsand limited number of triaxial tests were performed. Different binder's contents and different mixing proportions between binders were blended to prepare specimens using soils representtwo different layers ofSouth Port Said clay. The results of testing specimens afterdifferent curing time showed that dry mixing method can effectively improve strength and stiffness of Port Said clay.It was also concluded that cement waste can partially or fully replace cement and lime to improve Port Said clay by dry mixing method whilewith marble powder and limestone waste can partially be used with less effectiveness.
\end{abstract}

Keywords: Ground Improvement,Deep Soil Mixing, Dry Mixing Method, Cement Waste, limestonewaste, Marble powder.

\section{INTRODUCTION}

Deep mixing method (DMM)is currently accepted worldwide as a ground improvement technology to improve strength, deformation and permeability properties of soil. Bruce [1] defines DMM as the methods where various types of cementitious materials, binders, are blended into the soil. Binders are introduced through hollow, rotated shafts equipped with cutting tools, and mixing paddles or augers that extend for various distances above the tip. DMM has relative advantage as it does not require full soil replacement and can be used when soft soil layers extend deeply up to 40 $m$ depth. Krenn [2] reported thatDMM is often more economical than traditional methods, such as soil replacement and small diameter piles.DMM is classified by prEN 14679 [3] into dry deep mixing, DDM, and wet deep mixing, WDM, based on the medium of binder transferring. In dry mixing, the medium is compressed air while in wet mixing the medium is water.According to Bruce [1], DDM is preferred to improve the characteristics of cohesive soil where water tables are close to the ground surface.According to Allen [4]\& Carrie [5], DDM is used for soils with moisture content $>40 \%$ with $10 \%$ typical dosage by weight of soil (75 to $\left.200 \mathrm{~kg} / \mathrm{m}^{3}\right)$. Generally Port Said is characterized by the presence of thick layers of soft clay deposits and water table nearground surface. Golder [6] and Germanov [7],reported thatPort Said near surface clay layer extends to an average depth of $30 \mathrm{~m}$ and rests on basal and dense sand. South of Port Said city, the clay layer extends from the surface of the ground to few tens of meters depths

1 Prof. of Properties and Strength of Materials, Suez Canal University. 2 Prof. of Geotechnical and Foundation Engineering, Port Said University.

3 M.Sc. in Geotechnical and Foundation Engineering, Port Said University. before reaching dense sand layer.

Due to the presence of deep soft soil strata, using soil replacement becomes not possible.Accordingly alternative method to improve soil strength is needed. On the other side, the industries of cement, limestone and marble produce enormous amounts of by-products. New ideas in turning theses by-products into useful, instead of harmful, materials will have environmental and economic implications. This paper aims to examine the effectiveness of using dry deep mixing methodto improve strength properties of deep strata of soft clay using five different types of binders including cement, lime, cement waste, limestone waste and marble powder.

Studying the factors that may affect the improved soil strength by DMM and the utilization of different binders was the subject of many precedent studies.Kawasaki [8] studied the deep mixing method using cement hardening agentand concluded that compressive strength of cement treated clay increases with the increase of curing time. Taki [9] measured the unconfined compressive strength of different soil types treated with cement. Taki reported that, at the same cement content,coarse grained soil exhibited more increase in strength compared tofine grained soil.Åhnberg[10] studied the stress parameters of cement stabilized soil and concluded that the increase of shear strength is affected by the soil type, the initial water content and by the water/cement ratio.Uddin [11] found that the final compressive strength of the stabilized clay increases with the increase of cement content.Åhnberg [12] studied the difference in strength levels and rate of strength increase between different types of binders' composition and three Swedish soils.The conclusion of the performed unconfined compression tests was that, the optimal binder composition found for one soil would not be directly 
applicable to another soil as it varies considerably. Åhnberg [13] performed a series of laboratory tests on four soils stabilised with different types of binders to improve the understanding of the strength behaviour of stabilised soils. It was concluded that although the type of binder may strongly affect the rate of strength increase and the final strength, the general strength behaviour for soils stabilised by the most common binders is the same. It was also found that stabilised soils strength and deformation properties are similar to overconsolidated natural soilswhere the same parameters describing strength of natural soils can also be used for stabilised soils.

Başer [14] studied the effectiveness of using limestone waste and dolomitic marble powder, as binders, to control swell-shrink behaviour of expansive soils. T was found that swelling percentage decreased and rate of swell increased with increasing stabilizer percentage.Wayne [15] discussed the basic characteristics of cement waste andits wide variety of applications including agricultural soil enhancement, base stabilizing for pavements, wastewater treatment, wasteremediation, low-strength backfill and municipal landfill cover.Mohamadien [16] studied the effect of marble powder as partial replacement for cement on mortar and concluded that the compressive strength of mortar increased with timewhen $15 \%$ of cement content was replacement marble powder.

According to CDIT [17], without mix design studies using soils obtained from a project site, it is not possible to predict strength results from adding a particular amount of binder to a given soil. Accordingly to achieve the purpose of the present study, a series of laboratory tests on large number of specimens was performed. Specimens were prepared by mixing different types of binders' compositions with clay from the surface layer, soil1, or a near surface layer, soil2, from South Port Said.Subsequentlyand after different curing time intervals, a large number of unconfined compressive strength tests and limited number of undrained consolidated triaxial tests were performed to examine the strength properties of the mixed specimens. Laboratory preparation and testing of mixed specimens was discussed by Jacobson [18] for the dry method and by Filz [19] for the wet method. As the present study focuses on the dry mixing method, Jacobson procedures have been strictly followed. The laboratory test program is performed, results and discussions and conclusion are presented in next sections of this paper

\section{RESEARCH PROGRAM}

This section defines the materials used and describes studied parameters and tests performed to investigate the strength properties of Port Said stabilized clay by DDM.

\subsection{Material properties}

The present study included three different materials: the soil in its natural state (base soil), the agent used to stabilize soil (binder) and the altered soil when base soil was mixed with binder (mixed soil). The properties of each of the used material are presented below.

\subsubsection{Base soil properties}

Two soft soilshave been selected to represent the soft soil in the South area of Port Said. Soill was collectedfrom surface clay layer while soil2 was collected from lower clay layer around $10 \mathrm{~m}$ below ground surface. The location where samples were collected is shown in the below figure.

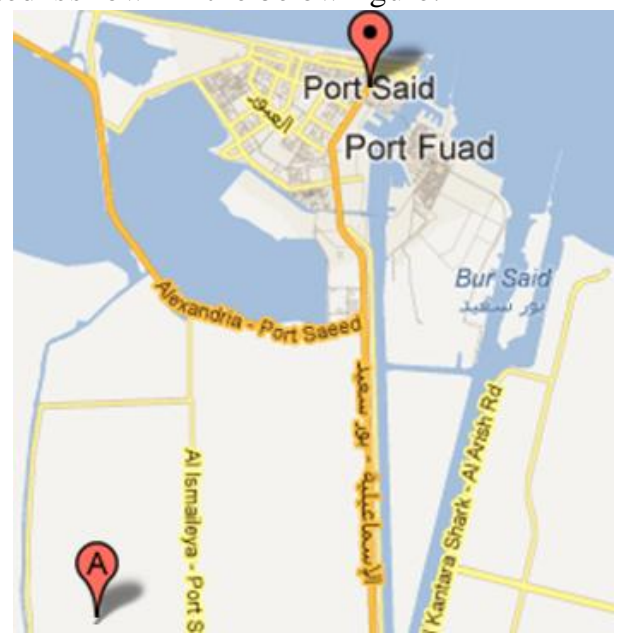

Figure (1) Locations (A) of base soil sampling

For both soils, undisturbed samples using Shelby tubes and bulkamounts of disturbed samples were collected. Precautionswere taken to prevent any cation exchange, oxidation or drying of samples.Laboratory tests to investigate base soils properties were performed in accordance with ECP 202/2 [20] and included the following:

- Particle Size Analysis (Hydrometer)

- Soil Moisture Content

- Atterberg Limits (Liquid Limit)

- Atterberg Limits (Plastic Limit)

- Bulk Unit Weight (Density)

- Specific Gravity (Particle Density)

- Unconfined Compressive Strength test, UCS

- Compressibility Index by Oedometer

- Consolidated Undrained, CU, Triaxial, Compression

The results of the performed tests are summarized in table (1):

According to the results presented in table (1) the initial water content of both soils was suitable for soil stabilization by DDM. In addition, and according to their very low shear strength $\left(<25 \mathrm{kN} / \mathrm{m}^{2}\right)$ both soils were classified as very soft clay.

\subsubsection{Binders properties}

Five binders were used.Each binder was given one letter symbol as follows: L for lime, $\mathrm{C}$ for cement, $\mathrm{P}$ for cement waste, $\mathrm{Q}$ for limestone waste and $\mathrm{M}$ for marble powder. Prior to mix with base soil, the properties of the five binders were identified. Cement, cement waste and lime properties were taken from the manufacturer. Limestone waste and marble powder properties were acquired as a result of cooperation with and support of Ibrahim [21] who studiedthe use of limestone waste and marble powder, obtained from the same sources, as filling materials to produce green concrete. Ibrahim provided the guidance for obtaining the materials and moreover allowed the use of the laboratory test results 
performed to identify the properties of limestone waste and marble powder.

Table (1). Original soils properties

\begin{tabular}{|c|c|c|c|c|}
\hline Property & Sym. & Unit & Soill & Soil2 \\
\hline \multicolumn{5}{|l|}{ Basic characteristics } \\
\hline Bulk density & $\gamma$ & $\mathrm{kN} / \mathrm{m}^{3}$ & 14.9 & 15.8 \\
\hline Specific Gravity & Gs & - & 2.65 & 2.67 \\
\hline Void ratio & $e$ & $\%$ & 1.8 & 1.4 \\
\hline Initial water content & $w_{t}$ & $\%$ & 115 & 89 \\
\hline Liquid limit & $L L$ & $\%$ & 123.5 & 112 \\
\hline Plastic limit & $P L$ & $\%$ & 48.25 & 34.15 \\
\hline Plasticity Index & $P I$ & $\%$ & 75.25 & 77.85 \\
\hline $\begin{array}{l}\text { Plasticity } \\
\text { Classification }\end{array}$ & - & - & $\begin{array}{l}\text { Highly } \\
\text { plastic }\end{array}$ & $\begin{array}{l}\text { Highly } \\
\text { Plastic }\end{array}$ \\
\hline \multicolumn{5}{|c|}{ Compressibility and consolidation characteristics } \\
\hline Compression index & $\mathrm{C}_{\mathrm{c}}$ & - & 0.798 & 0.704 \\
\hline Recompression index & $\mathrm{C}_{\mathrm{C}}$ & - & 0.0216 & 0.0229 \\
\hline $\begin{array}{l}\text { Coefficient of } \\
\text { consolidation }\end{array}$ & $\mathrm{C}_{\mathrm{V}}$ & $\mathrm{m}^{2} / \mathrm{y}$ & 3.5 & 4.7 \\
\hline \multicolumn{5}{|c|}{ Strength-strain characteristics } \\
\hline $\begin{array}{l}\text { Unconfined } \\
\text { compression strength }\end{array}$ & $U C S$ & $\mathrm{kN} / \mathrm{m}^{2}$ & 10 & 20 \\
\hline Strain at Failure & - & $\%$ & 17 & 15.7 \\
\hline Clas sification & - & - & Very soft & Very soft \\
\hline Undrained cohesion & $c$ & $\mathrm{kN} / \mathrm{m}^{2}$ & 8 & 15 \\
\hline $\begin{array}{l}\text { Undrained friction } \\
\text { angle }\end{array}$ & $\varphi$ & degree & 7 & 9 \\
\hline Grain size distribution & $\mathrm{D}_{50}$ & $\mathrm{~mm}$ & 0.008 & 0.003 \\
\hline from 0.6 to $0.06 \mathrm{~mm}$ & & $\%$ & 8 & 0 \\
\hline $\begin{array}{llll}\text { from } 0.06 & \text { to } & 0.002 \\
\mathrm{~mm}\end{array}$ & & $\%$ & 38 & 5 \\
\hline$<0.002 \mathrm{~mm}$ & & $\%$ & 60 & 95 \\
\hline
\end{tabular}

Different chemical processes in soil stabilisation using different binders have been described in many previous studies such as Janz [22] and Chew [23].According to Åhnberg [13], the reactions generated when mixing various binders with soil vary by process, intensity and duration, but in general, exhibit many similar characteristics. There is no substantial change in the principal types of reaction products and bonds formed. As concluded by Taylor [24], the various binders can be characterised with respect to possible type and rate of reactions by looking at their content of $\mathrm{CaO}, \mathrm{Al} 2 \mathrm{O} 3$ and $\mathrm{SiO} 2$. In general, the reactivity increases with total content of $\mathrm{CaO}+\mathrm{Al} 2 \mathrm{O} 3+\mathrm{SiO} 2$ of the binders.

Accordingly and due to the expected effect of the binder type on the strength behaviour of mixed soil, the physical properties and chemical composition of the five used binders is presented briefly below.

\section{a) Lime $\mathbf{L}$}

The word lime in the present study refers to quicklime $(\mathrm{CaO})$ which when mixed with soil absorbs moisture in the soil and becomes hydrated lime. This hydration generates a large amount of heat and reduces soil water content and slightly increases shear strength.With enough pore water hydrated lime dissolves and increases calcium and hydroxyl ions. This high concentration of hydroxyl ions (high $\mathrm{pH}$ ) silica and aluminium in clay minerals react with calcium to form a tough waterinsoluble gel of calciumsilicate and calcium aluminate.
This reaction, which is called pozzolanic reaction, proceeds as long as the $\mathrm{pH}$ is high and cements the clay particles together and increases soil strength considerably.

Lime used in the present study was quicklime manufactured by Suez Lime Companyaccording to ES584/2003 [25].The physical properties of the used lime are shown in the below table:

Table (2). Lime physical properties

\begin{tabular}{|l|c|c|}
\hline Property & Unit & Value \\
\hline Fineness & $\mathrm{m}^{2} / \mathrm{kg}$ & 660 \\
\hline Alkalinity $(\mathrm{pH})$ at $25 \mathrm{C}^{\circ}$ & - & $11.4-12.4$ \\
\hline Bulk Density & $\mathrm{kg} / \mathrm{m} 3$ & $720-1130$ \\
\hline Specific gravity & - & $3.2-3.4$ \\
\hline
\end{tabular}

\section{b) Cement $\mathbf{C}$}

Portland cements are compounds of calcium silicate and calcium aluminate with a small proportion of gypsum. They are produced by burning materials which contain predominantly calcium carbonate, aluminium oxide, silica and iron oxide, at a temperature exceeding $\mathrm{I} 400^{\circ} \mathrm{C}$. The cooled clinker is ground under controlled conditions with the addition of 5\% gypsum. Due to CDIT [17], the standard cement type stabilizing agent is Portland cement. When mixed with soil, cement minerals, for example $\mathrm{Ca}_{3} \mathrm{SiO}_{5}$, react with pore water and produce cement hydration products which have high strength that increases with age. In addition the hydration reaction releases calcium hydroxide which contributes in pozzolanic reaction as in lime stabilization.

The used cement in the present study was Ordinary Portland Cement (OPC) produced by Lafarge Cement factory, in Sukhna road, Suez, with strength class CEM- I $42.5 \mathrm{~N}$ and brand name Momtaz. According to the product datasheet, as provided by the manufacturer, the physical properties of the cement are as below:

Table (3). Cement physical properties

\begin{tabular}{|l|c|c|c|}
\hline Property & Unit & Value \\
\hline Fineness & $\mathrm{m}^{2} / \mathrm{kg}$ & 310 \\
\hline Compressive Strength of & 2 days & $\mathrm{kN} / \mathrm{m}^{2}$ & 20000 \\
\cline { 2 - 4 } Standard Mortar & 28 days & $\mathrm{kN} / \mathrm{m}^{2}$ & 49000 \\
\hline \multirow{2}{*}{ Setting time } & initial & minute & 150 \\
\cline { 2 - 4 } & final & minute & 180 \\
\hline
\end{tabular}

\section{c) Limestone waste $\mathbf{Q}$}

Limestone waste is generated as a by-product during the production of aggregates through the crushing process of rocks in rubble crusher units. Limestone waste was collected from local crusher at Suez Quarries (Attaka, Quarries, EL-Suez Area). The tests were performed in accordance with EC 203/2007 [26] and ESS 1109/2002 [27] where physical properties of used limestone waste are summarized in the below table:

Table (4). Limestone wastephysical properties

\begin{tabular}{|l|c|c|}
\hline Property & Unit & Value \\
\hline Specific Weight & - & 2.61 \\
\hline Bulk density & $\mathrm{kg} / \mathrm{m}^{3}$ & 1680 \\
\hline Fine Dust Content & $\%$ & 15.17 \\
\hline Water Absorption & $\%$ & 2.1 \\
\hline
\end{tabular}

Table (5). Marble powder physical properties \begin{tabular}{|l|c|c|}
\hline Property & Unit & Value \\
\hline
\end{tabular} 


\begin{tabular}{|l|c|c|}
\hline Specific surface area & $\mathrm{m}^{2} / \mathrm{kg}$ & 1140 \\
\hline Bulk density & $\mathrm{kg} / \mathrm{m}^{3}$ & 986 \\
\hline Specific gravity & - & 2.5 \\
\hline Colour & - & Light grey \\
\hline
\end{tabular}

\section{d) Cement waste $P$}

Cement waste is a by-product generated as a result of the manufacture of cement during the calcining process in the kiln. In Egypt more than 50 million ton of cement waste is generated annually.

Some of the generated waste is recycled back again with the clinker. However, most of the material is usually disposed of without any further reuse or reclamation.Cement wasteused in the present paper has been brought from Lafarge Suez Cement, cement factory in Sukhna, Suez. The physical properties of the cement waste are summarized in the belowtable:

Table (6). Cement wastephysical properties

\begin{tabular}{|l|c|c|}
\hline Property & Unit & Value \\
\hline Passing from sieve no. 200 & $\%$ & 85 \\
\hline Plasticity index & - & 2 \\
\hline Specific gravity & - & 2.7 \\
\hline Absorption & $\%$ & 1 \\
\hline
\end{tabular}

The chemical properties of the five used binders in the present study are summarized in the below table:

Table (7). Binders chemical properties

\begin{tabular}{|c|c|c|c|c|c|}
\hline Properties & Ce ment & Lime & Quarry & Marble & Bypass \\
\hline $\mathrm{CaO}$ & - & 93.0 & 34.95 & 42.14 & 51.5 \\
\hline $\mathrm{Al}_{2} \mathrm{O}_{3}$ & - & 0.6 & 0.76 & 2.69 & 3.25 \\
\hline $\mathrm{SiO}_{2}$ & - & 1.4 & 6.49 & 14.08 & 8.5 \\
\hline $\mathrm{K}_{2} \mathrm{O}$ & - & $<0.1$ & 0.10 & 0.63 & 5.5 \\
\hline $\mathrm{Fe}_{2} \mathrm{O}_{3}$ & - & 0.3 & 0.36 & 1.94 & 2.25 \\
\hline $\mathrm{MgO}$ & - & 1.0 & 14.44 & 2.77 & 0.73 \\
\hline $\mathrm{SO}_{3}$ & 2.9 & $<0.1$ & 0.04 & 0.08 & 3.25 \\
\hline $\mathrm{Na}_{2} \mathrm{O}$ & 0.5 & $<0.1$ & 0.67 & 0.91 & 5.25 \\
\hline $\mathrm{CL}$ & 0.06 & - & 0.67 & 0.04 & 10.5 \\
\hline $\mathrm{Ca}_{3} \mathrm{SiO}_{5}$ & 60 & - & - & - & - \\
\hline $\mathrm{Ca}_{2} \mathrm{SiO}_{4}$ & 20 & - & - & - & - \\
\hline $\mathrm{Ca}_{3} \mathrm{Al}_{2} \mathrm{O}_{4}$ & 7 & - & - & - & - \\
\hline $\mathrm{Ca}_{4} \mathrm{AlnFe}_{2-}$ & 11 & - & - & - & - \\
${ }_{n} \mathrm{O}_{7}$ & & & & & \\
\hline
\end{tabular}

\subsection{Test program}

To investigate the properties of improved soil by dry mixing method, a large number of unconfined compressive strength (UCS) tests on samples prepared from two types of Port Said clay mixed with one or more binders in different proportions and different binders' contents were performed in addition to limited number of undrained consolidated triaxial tests.

\section{Prior mix preparation}

Prior to mixwith binders, base soil was hand blended till uniformity. When soil was collected from more than one bulk it was left for 24 hours prior to be mixed for water content to spread and homogenize. Combinations of binders wereblended prior to be mixed with soil.

\section{Specimens'size}

Specimens were prepared in cylinder shape of height to diameter ratio of $2(50 \mathrm{~mm}$ diameter and $100 \mathrm{~mm}$ height.To facilitate samples extraction, the molds were

divided longitudinally into two pieces then assembled using metalO-ring fastener as shown in figure (2a).

\section{Parameters studied}

The strength properties of Port Said stabilized clay by dry deep mixing, DDM, were studiedconsidering the following parameters:

- The effect of soil type: soil 1 and sloi2 were tested.

- The effect of binder type: five binders including cement, lime, cement waste, limestone waste and marble powder were used.

- The effect of binder content: where amounts equivalent to 50,100 and $150 \mathrm{~kg}$ of binder, or combination of binders, to $\mathrm{m}^{3}$ ofbulk soil were used.

- Different mixing combination: where each of cement, lime and cement waste were used alone and mixed with anothertype of the other four binders.

- Combination with different percents: where the mixtu re of two binders was tried in $75 / 25,50 / 50$ and 25/75 percents between binder 1 and binder 2 .

- Curing time: wherespecimens were tested after 7, 30 and 90 days of preparation.

\section{Specimens' identification}

A unique ID has been given to each tested specimen. An example of specimen ID is illustrated below:
Symbol : S1-050-CL-1:1-30
S1 : Soill
050 : Amount of binder in $\mathrm{kg} / \mathrm{m}^{3}$ (binder content)
CL : Cement and Lime
1:1 : Mixing ratio, similar to percent of $50 / 50$
30 : Curing time in days

\section{Specimens' preparation}

The specimens' preparation followed the steps developed byJacobson [18].The predetermined amounts of soil and binders were mixed in a bowl of four litres mechanical mixer for 5 minutes. At three evenly spaced times, the mixer was stopped and a spatula was used to scrape soil from the sides of the bowl, placing it back into the mix. As shown in figure (2b), size ' $A$ ' molds were labeled and graced by oil then filled in three lifts where each lift was blended softly by hand then a 100 kpa pressure was applied to the top of the lift for approximately 10 seconds .

\section{Curing and storage}

After preparation specimens were isolated by wax then storedin foam box then sealed and put insider bigger size foam box partially filled with water and stored in room temperature as shown in figure (2c)

(a)

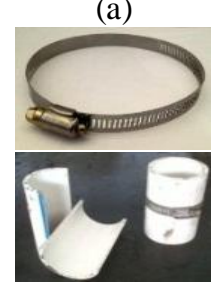

(b)

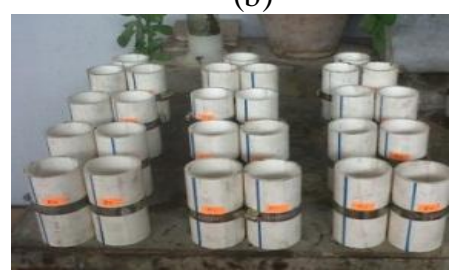


(d)
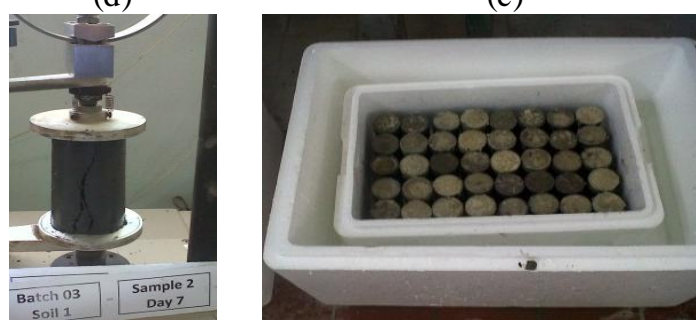

Figure (2) Samples preparation, storage and testing

\section{UCS Testing}

To investigate the strength behaviour of the specimens, unconfined compression tests were performed after 7, 30 and 90 days of curing. Before performing the tests, specimens' ends were cut and smoothed to form parallel end surfaces. Then the UCS tests were performed with a rate of $1 \mathrm{~mm} / \mathrm{min}$ as shown in figure (2d).The densities and water contents of samples were determined.

Due to the large number of UCS tests performed in the present study, tests wereparted between soil mechanics lab of Suez Canal Authority Research Centre and soil mechanics lab in Ain Shams University.

\section{Triaxial Testing}

To investigate the effect of soil stabilization by adding different mixtures of binders on the strength evaluated from triaxial test, a limited number of consolidated undrained triaxial tests was performed. All triaxial tests on mixed soil specimens were performed in the soil mechanics lab in Ain Shams University. This was to benefit from the high capacity of rings available where high capacity was needed to test mixed soil specimens.

Specimens were consolidated for 24 hours before the start of the actual shear test. A ring of $200 \mathrm{~kg}$ strength was used and the used rate was $0.4 \mathrm{~mm} / \mathrm{min}$.

The minor principle stress used, $\sigma_{3}$ was used with values of 100,200 and $300 \mathrm{kN} / \mathrm{m}^{2}$. Tests have been performed on specimens after 90 days curing time.

\section{RESULTS AND DISCUSSION}

\subsection{Unconfined Compression Strength UCS Results verification}

Unconfined compressionstrength of soil1 and soil2 in their original state was, $0.1 \quad \mathrm{~kg} / \mathrm{cm}^{2}$ and 0.20 $\mathrm{kg} / \mathrm{cm}^{2}$ respectively.The liquid and plastic limits for soill were $123.5 \%$ and of $48.25 \%$ and for soil2 limits were 112 $\%$ and $34.15 \%$. Accordingly both soils where classified as very soft clay with high plasticity.

As mentioned in CDIT [17], stress strain curve of Tokyo Port clay, soft clay with liquid limitof $93.1 \%$ and plastic limitof $35.8 \%$, is characterized by small strength and large strain at failure. On the contrary, whenmixed with $112 \mathrm{~kg} / \mathrm{m}^{3}$ of Portland cement the stress-strain curve of treated clay turned to be of very high strength and small strain at failure. This was related to the high increase in shear strength and large reduction in strain at failure due to soil stabilization.

The stress-strain curves for soill and soil2 in the original state and mixed state with $100 \mathrm{~kg} / \mathrm{m}^{3}$ of cement, after 30 days of curing, were plotted in figure (3) against Tokyo Port clay curves. From the figure it can be concluded that both soils have shown similarstress strainbehaviour toTokyo Port clay in both original and mixed states. Soill has shown strength increase of (30 times)from original clay strength with the strain at failure reduced from $17 \%$ to $1.6 \%$ ( $1 / 10$ of original strain). For soil2 strength was increased to 20 times of original value with a strain reduction from $15.5 \%$ to $1.5 \%$ (1/10 of original value also).

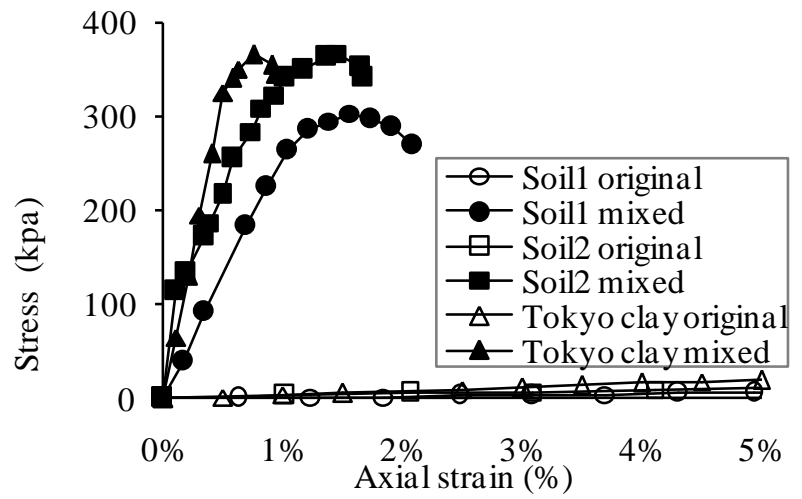

Figure (3) Stress strain curve for original and mixed soil.

Accordingly, it can also be concluded that deep mixing stabilization is effective method in increasing strength and reducing strain for both soils

\section{Curing time effect}

Kawasaki [8] and Uddin [11] reported that the compressive strength of cement treated clay increases with the increase of curing time. Saitoh [28] reported that the compressive strength ratio at 28 days to 7 days ranged from 1.2 to 2.1. Porbaha [29] observed that the compressive strength increases with rapid rate in the early curing periods then continues increasing with time but at a decreasing rate. According to EuroSoilStab [30] the effect of time differs between different mixes of binders and soil. When using only cement as binder the stabilisation reactions almost completed during the first month while may continue several months when using lime, furnace slag, gypsum or fly ash.

In the present study, time strength development forbindersmixed in 50/50 percent of cement to other binder with binder content of $100 \mathrm{~kg} / \mathrm{m}^{3}$, is shown below.

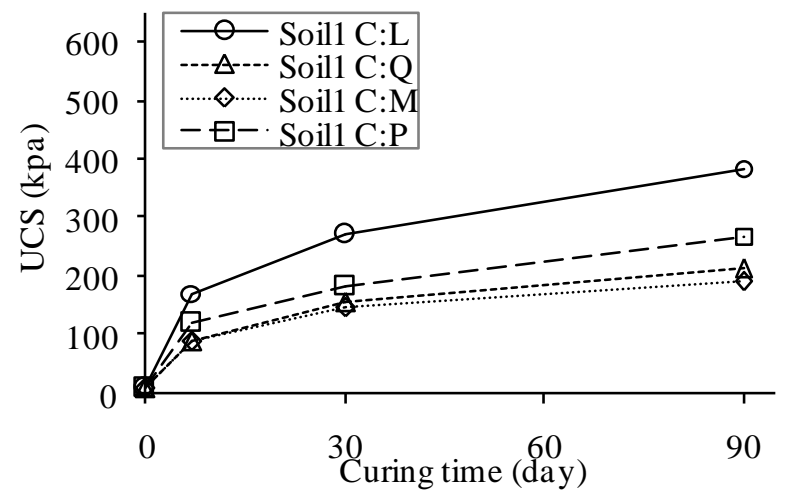

Figure (4) Soillstrength development with time 


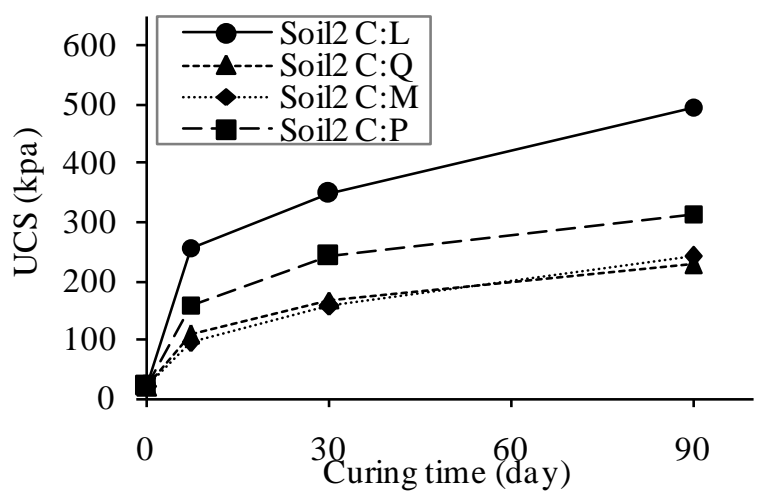

Figure (5) Soil2strength development with time

From figures ( $4 \& 5$ ) it can be concluded that for all mixed binders, the rate of strength increase is very high for the first week then decreases with time. It can also be concluded that cement with lime has shown the highest strength increase then with cement waste for both soils.

\section{Curing time with one binder}

Figure (6)shows UCS for different curing time for 100 $\mathrm{kg} / \mathrm{m}^{3}$ for cement, lime and cement waste each mixed alone with soill and soil2. Cement has shown the highest strength increase. Cement wastehasincreased strength slightly higher than lime.

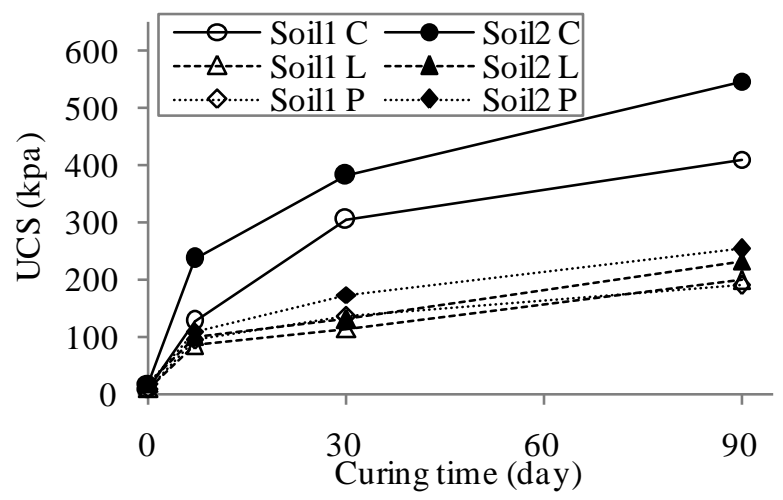

Figure (6) The effect ofsole binders mix on UCS

Accordingly it can be argued thatcement waste can fully replace limeeffectively.

\section{Binders' content effect}

According to CDIT [17]the unconfined compressive strength increases almost linearly with increasing the amount of cement. Moseley [31] reported that, often higher undrained shear strength can be obtained with lime/cement than with lime and this strength increases, in general, with increasing lime/cement content.

In the present study the effect of binder amount on soil strength increase is shown in figure $(7 \& 8)$. The curves presented show different binders contents of cement with other binders in $50 / 50$ percent. It can be concluded that for both soils and with all mixed binders the strength increases almost linearly with binder content increase particularly after $50 \mathrm{~kg} / \mathrm{m}^{3}$ binder content. However it can be noticed that the rate of strength increase is slightly higher with the higher binder content particularly with limestone waste and marble powder. Accordingly it can be argued that the partial replacement of cement by limestone waste and marble powder is more effective in soil stabilization by is better with higher a mount of binders (higher than $100 \mathrm{~kg} / \mathrm{m}^{3}$ )

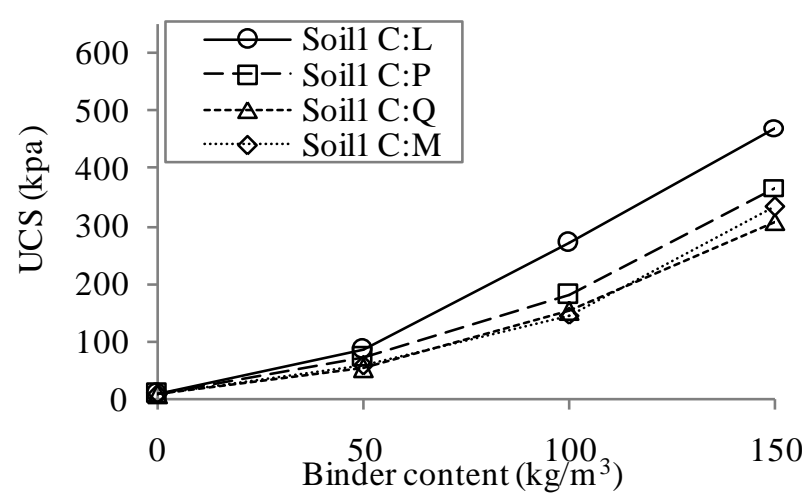

Figure (7) Binder contenteffect on UCS for soill

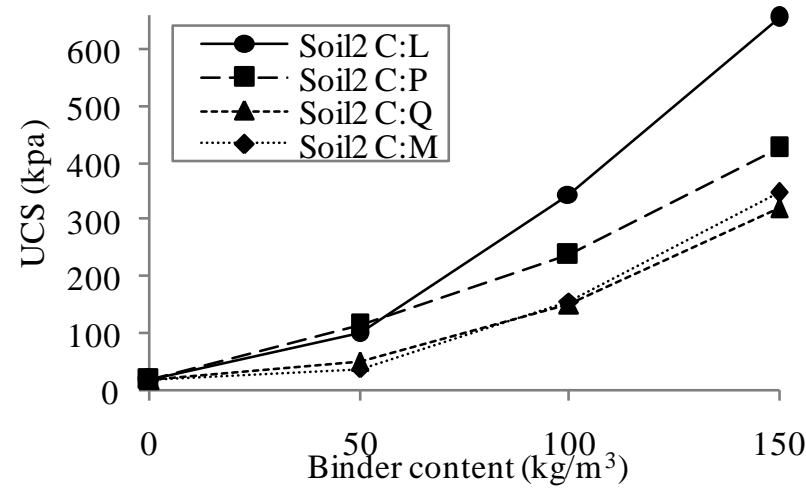

Figure (8) Binder content effect on UCS for soil2

\section{Combination of cement waste\& other binders}

At the early stage of the present study, equal attention was paid to the three tried by-product materials. With timeit was noticed that cement waste was the most effective tried by-product when partially replacedcement andlime. Among the three tried by-products, cement waste was the only one thatcould fully replace cement and lime as a pure binder. Accordingly it was decided to investigate the effectiveness of using cement waste in combination with the other two by-products.

In figure $(9 \& 10)$, the strength increase with time for different binders mixed with cement wastein 50/50 percent(with $100 \mathrm{~kg} / \mathrm{m}^{3}$ binders' content)is compared with cement/ lime mix results.From the figure it concluded that the mix of cement waste with other byproducts can be used with less efficiency than cement or lime.

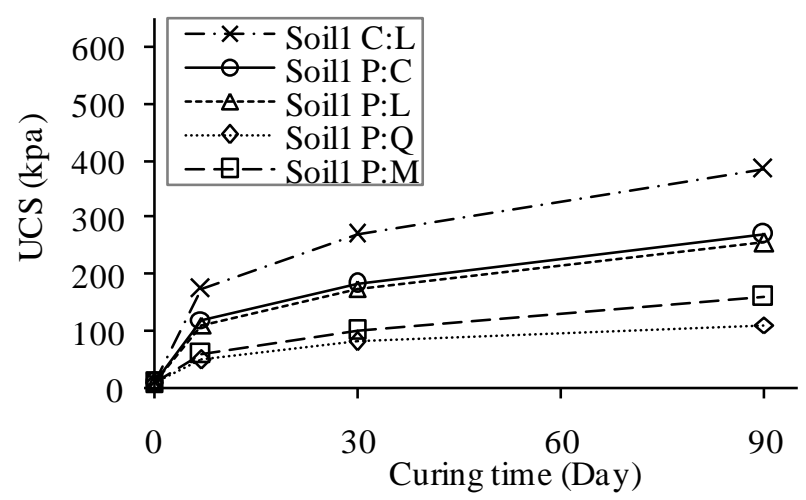

Figure (9) UCS of cement waste mixes for soill 


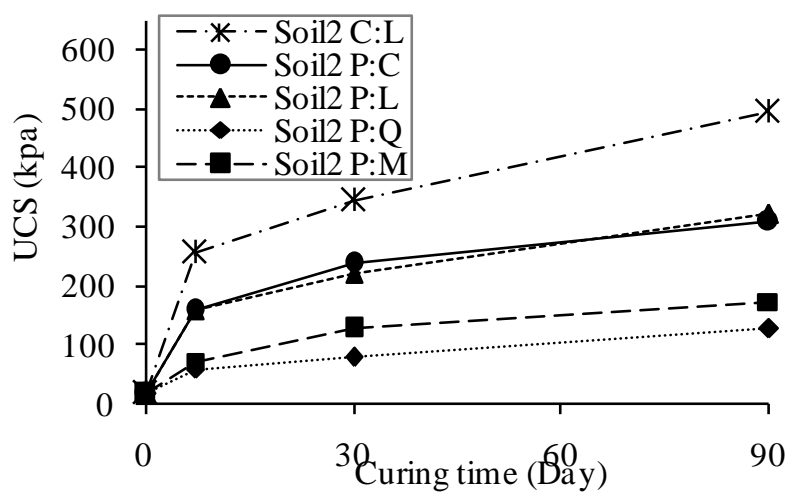

Figure (10) UCS of cement waste mixes for soil2

It was also possible to conclude that the combination of cement waste and marble powder is slightly more effective than cementwaste with limestone waste.

\subsection{Undrained shear strength}

Moseley [31] reported that often higher undrained shear strength is obtained with lime/cement than with lime alone. Green [32] reported values between $30^{\circ}$ and $40^{\circ}$ for mixed soil friction angle $\left(\varphi_{u, c o l}\right)$ by direct shear tests with lime/cement $(50 / 50$ and $80 / 20)$ while frictionangles of $33^{\circ}$ and $41^{\circ}$ were obtained by triaxial tests.Åhnberg [13] found that the cohesion of mixed soil varied between $50 \mathrm{kpa}$ for claysstabilized with lime to $1600 \mathrm{kpa}$ for clayey silt stabilized with cement.

In the present study, samples prepared for mixing 100 $\mathrm{kg} / \mathrm{m}^{3}$ of cement andone of the other four binders in $50 / 50$ percent were tested after 90 curing days by undrained consolidated triaxial tests.

As shown in figure (11) below, cohesion strength calculated from UCS, based on the assumption that Cohesion $=0.5 \mathrm{UCS}$, is compared with the cohesion strength calculated by triaxial test. It was found that the cohesion from triaxial test ranges between 0.37 and 0.43 of UCS value for all of the tested samples.

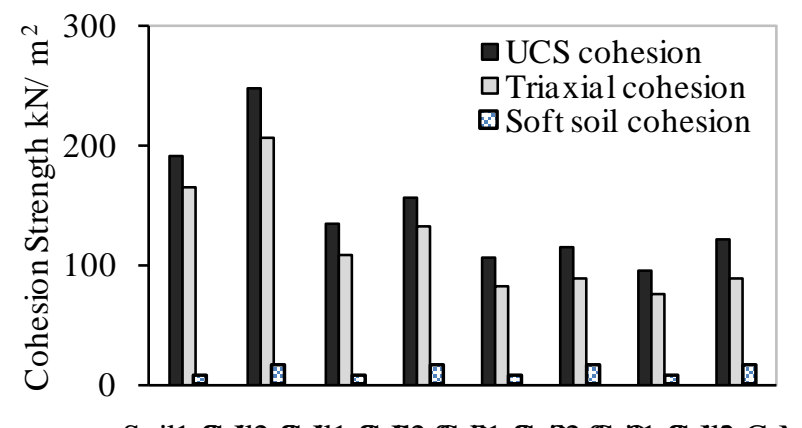

Soill Eoll2 Gorl1 GoH2 SoP1 Go(12 SOD1 GoN2 C:N

Figure (11) Cohesion strength from triaxial and UCS

The friction angles of mixed soils were compared with the friction angles of original soilsas shown in figure (12). According to the results the friction angle has increase for both mixed soils with all used binders however the increase was higher for cement then lime binders than the other used binders.

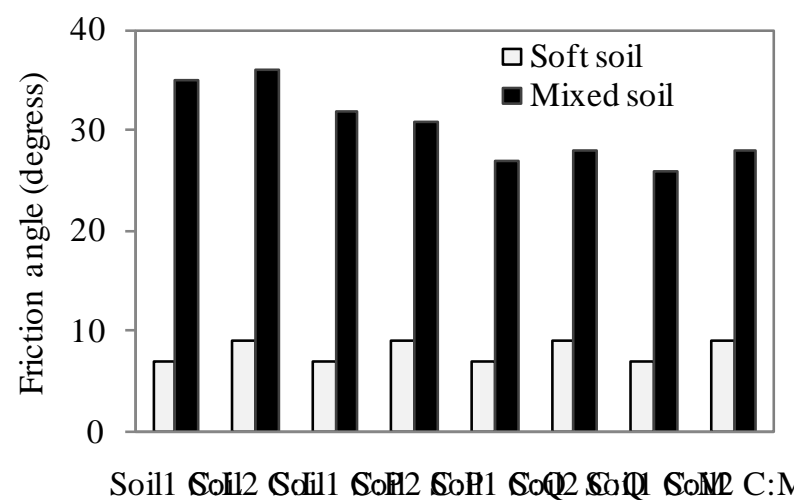

Figure (12) Soil stabilization effect on friction angle

Based on triaxial tests results it can be concluded that triaxial tests have confirmed the effect of soil stabilization to increase soil strength considerably. This increase depended on increasing both cohesion strength and friction angle.

\subsection{Modulus of elasticity}

According to EuroSoilStab [30] fairly linear relationship exists between $E_{50}$ and max. UCS strength $q_{u}$ and generally falls in the range 100 200 $q_{u}$. Based on Terashi [33] the value of $E_{50}$ for quicklime treated soil is 75 200 $q_{u}$ when $q_{u}$ is less than $1500 \mathrm{kpa}$ and 200 to $1000 q_{u}$ when $q_{u}$ exceeds $1500 \mathrm{kpa}$. Lorenzo [34] found the correlation of $E_{50}$ to $q_{u}$ of Cement treated Bangkok clay to be $115 \sim 150 q_{u}$.

The effect of mixing different binders, with soill and soil2, on the stiffness and the correlation between the strength and stiffness for mixed soils is presented in this section. According toEuroSoilStab [30]the stiffness modulus of elasticity $\mathrm{E}$ is taken from the pre-failure part of a typical stress-strain curve from unconfined compression test. The usual values derived from the unconfined or triaxial test are the secant modulus $E_{50}$ (at value of stress equal to $50 \%$ of failure stress).

In the presentpaper, the secant modulus $E_{50}$ from UCS curves was used to represent soils stiffness in its original and mixed states.The relationship between $E_{50}$ and $q_{u}$, after 90 days, for both soill and soil2 with binder content of $100 \mathrm{~kg} / \mathrm{m}^{3}$ composed $50 / 50$ of cement andone of the other binders is shown in figure $(13 \& 14)$.

From the figures it is clear that the relationship between $E_{50}$ and $q_{u}$ is almost linear for mixedsoils with all binders combinations. As shown also the combination of cement with lime has shown the higher stiffness increase than all other three binders. It can also be argued that soill has higher rate of stiffness increase than soil2 although final values of soil2 are higher. 


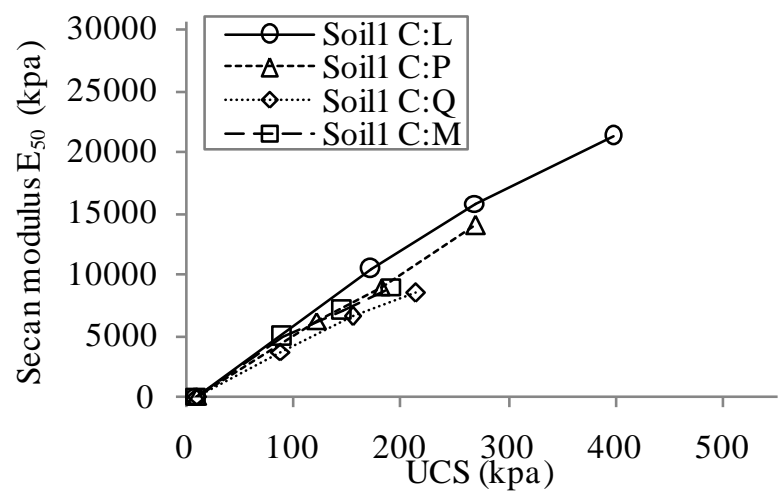

Figure (13) $E_{50} / q_{u}$ ratio for mixed soill

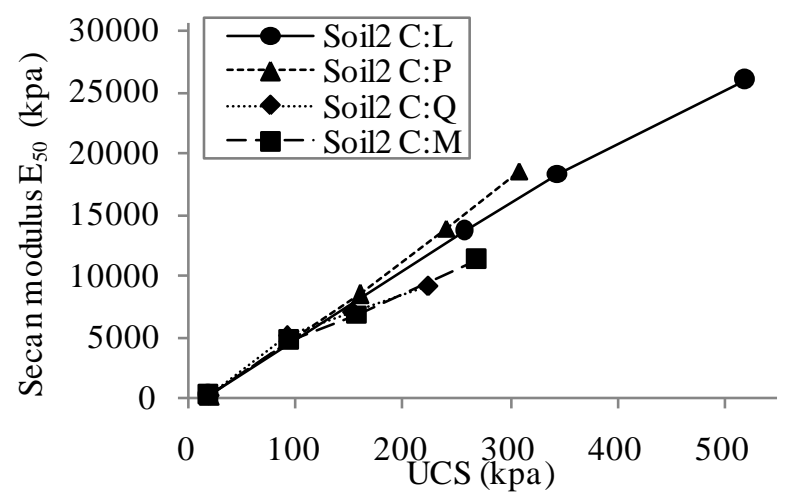

Figure (14) $E_{50} / q_{u}$ ratio for mixed soil2

Similar linear relationship between $E_{50}$ and $q_{u}$ has been noticed when binders, (cement, lime and cement waste) were used as purebinders with soill or soil2 in $100 \mathrm{~kg} / \mathrm{m}^{3}$ as shown in figure (15) below. From the figure it can be concluded that cement has the highest stiffness increase valuesfor both soils.

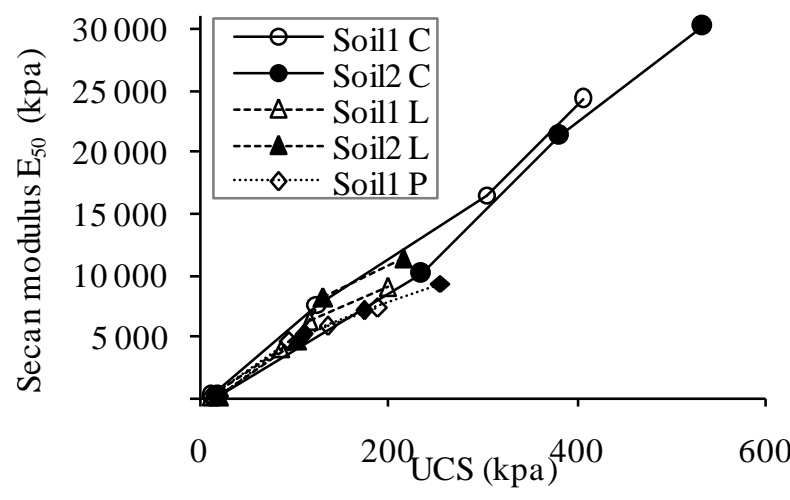

Figure (15) $E_{50} / q_{u}$ ratio for pure binders

For binder content of $100 \mathrm{~kg} / \mathrm{m}^{3}$ and curing time of 90 days, the values of soil stiffness for mixed soil and soft soil were co mpared in figure (16)

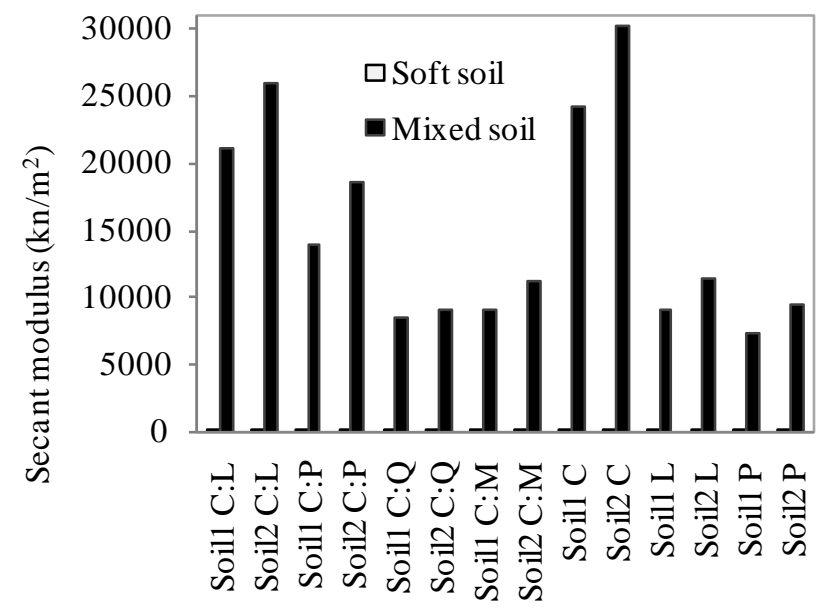

Figure (16) $E_{50}$ valuesfor soft and mixed soil

In general for both tested soils with different mixing combinations of binders the relationship between $E_{50}$ and $q_{u}$ falls within the range of $40 \sim 70 q_{u}$.Pure cement has shown the highest stiffness increase for both soils followed by cement lime combination. Pure lime and pure cement waste have shown close rates of stiffness increase with both soils. On the other side the ratio between mixed soil to soft soil stiffness range was within the values of $60 \sim 280$.

\subsection{Water content}

CDIT [17] has presented the results of Tokyo Port Clay mixed with Portland cement in amounts varied from 100 to $135 \mathrm{~kg} / \mathrm{m}^{3}$ with a water-cement ratio (0.6). Despite the scatter in results, it was possible to conclude that the water content decreased around $20 \%$ from the initial water content.The results of the laboratory studies performed by Åhnberg [13], Chew [23] andLoren zo [34] have indicated that with various types of binders, the water content decreases for any treated clays.

In the present paper, both tested soils were characterized by high initial water content, $115 \%$ and $89 \%$ for soil 1 and soil 2 respectively. The effect of mixing binders to soill and soil2 in different mixing percents, with amount of $100 \mathrm{~kg} / \mathrm{m}^{3}$, is shown in figure (13) below.

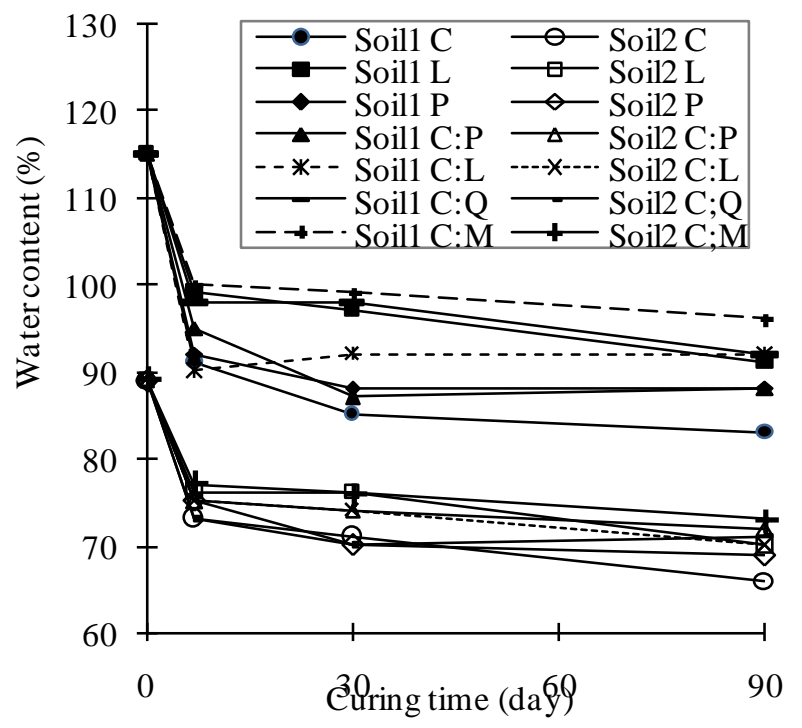

Figure (17) Effect of different binders on water content 
It can be concluded from the figure that water content decreased with different percents ranging from $13 \%$ of its original state till $28 \%$ of the original water content. The maximum reduction of water content was observedwithpure cement mixwith soill. From the results it can be concluded that the cement has the maximum reduction effect on water content for both soils. Cement waste has shown higher reduction effect on soil water content than lime while the effect of marble dust on water content was the lowest.In addition it can be concluded that binder mixingreduction effecton water content takes place with higher rate during the first week then the rate becomes slower afterwards.

\subsection{Density}

According to Åhnberg [13], certain increase in the bulk density and decrease in water content can beexpected when binders are mixed with soft soils. These changes normally leadto an increase in strength, as well as a decrease in compressibility.Mamunul [35] has studied the engineering characteristics of cement stabilized soft finished clay and concluded that treated soil tends to show higher values of dry and bulk density than original soil although sometimes bulk density remains the same or decreases. Kamata [36] reported that the increase in density due to lime treatment is relatively small. According to CDIT [17]the density increase of cement treated soil waswithin the range of 3 to $15 \%$ irrespective water/ cement ratio.

According to figure (18) both tested soils have shown tendency towards bulk density increase with all mixed binders. Generally, most of the tested samples have shown higher density increase during the first week after soil mix with binder.The density increase with different mixing compositions was relatively scattered when the trend of binder effect was considered while the trend with curing time was possible to be described by a slightly increasing trend.

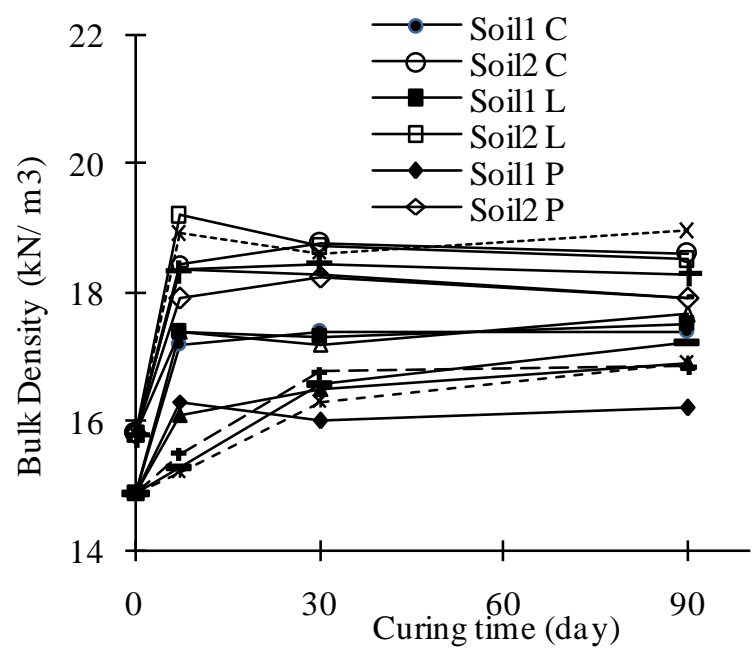

Figure (18) Effect of different binders on soil density

\section{CONCLUSION}

In the present paper, the effectiveness of dry deep mixing method to improve Port Said clay was studied. Specimens from soils represent two different layers of clay in South area of Port Said were mixed in the laboratory with different types of binders. The utilized binders included cement, lime, cement waste, limestone waste and marble powder. Different binders' contents and proportions were blended to prepare specimens. After different curing times, large number of compression tests and limited number of triaxial tests were performed. From analysing the results of the parameters studied the below conclusions were derived:

- Both tested soils have shown very good response to strength increase and compressibility reduction with the common binders, cement and lime. Consequently, it can be argued that soil improvement by dry deep mixing can be effectively used to improve strength and stiffness properties of Port Said clay.

- For100 kg/m $\mathrm{m}^{3}$ binder content,strength increased after 90 days upto4land 28 times for soill and soil2 respectively. The stiffness increased up to 282 and 162 times for soill andsoil2 respectively.

- For Port Said clay, pure cement was the most effective and quickest binder while cement waste was the most effective by-product binder in strength and stiffness increase.

- The effectiveness of using marble powder and limestone wasteto increase strength was low particularly with $50 \mathrm{~kg} / \mathrm{m}^{3}$ binder content then increased fairly when amount of mixed binder increased to $150 \mathrm{~kg} / \mathrm{m}^{3}$.

- For all blended combination of binders, strength, the rate of strength increase and compressibility reduction was higher during the first week then the improvement effect continued but with less rate.

- For all tested binders, nearly linear relationship between binder content and strength increase was noticed

- For both soils with all tested binders, triaxial tests results have showncompressibility reduction and strength increase fairly similarity with UCS tests.

- The cohesion strength calculated by triaxial test was found to fall between 0.37 and 0.43 of UCS value for all testedcombination of binders.

- Friction angles of mixed soils increased to values up to $36^{\circ}$ and $38^{\circ}$ from original values of $7^{\circ}$ and $9^{\circ}$ for soill and soil 2 respectively.

- In general, the dry mixing has shown reduction effect on water content with values ranging from $13 \%$ to $28 \%$ with the highest reduction value recorded with cement and the lowest reduction value recorded with marble powder.

- Similarly both tested soils have shown tendency towards bulk density increase with all mixed binders particularly during the first week.

\section{Acknowledgement}

I especially want to thank the whole team of soil mechanics lab and materials and quality control labat Suez Canal Authority Research Centre where all tests on base soil and all specimens' preparations and part of mixed soil tests were performed. I also thank the team of soil mechanics lab at Ain Shams University where part of tests on mixed specimens was performed.I am also grateful to A/ Prof. H. Mohamadien, Suez Canal University, for his great support and valuable advices. 


\section{References}

[1] Donald A. Bruce (2001), "An Introduction to The Deep Mixing Methods as Used in Geotechnical Applications. Volume III: The verification and properties of treated ground." Federal Highways Admin istration, FHWA-RD-99-167.

[2] Krenn H. \& Karstunen M. (2008), "Numerical Modelling of Deep Mixed Columns Below Embankments Constructed on Soft Soils" Proceedings of The Second International Workshop on Geotechnics of Soft Soils, Glas gow, Scotland, 3-5 Septe mber 2008

[3] European Standard prEN 14679 (2003)," Execution of Special Geotechnical Works - Deep mixing", European Committee For Standardization, Worldwide for CEN National Members

[4] Allen L. Sehn (2009). "Design and Applications of Deep Mixing Columns". 33 ${ }^{\text {rd }}$ Annual ASCE Iowa Section Geotechnical Conference.Stoney Creek Inn and Conference Centre.

[5] Carrie Johnson, P.E. (2012), “A Soil Improvement Primer", Structure Magazine, National Council of Structural Engineering Associations, NCSEA, March 2012

[6] Golder Associates (1979), "Geotechnical Report for Port-Said Area", Government of Port-Said, Port-Said, Egypt.

[7] Germanov T., El Azab M. (1995), “Geotechnical Properties Of Port-Said Clays", Annuaire De L'unversite D'architecture, De Genie Civil Et De Geodesie - Sofia

[8] KawasakiT., NiinaA., SaitohS., Suzuki Y.and Honjyo Y.(1981) "Deep Mixing Method Using Cement Hardening Agent", Proceedings of the 10th International Conference on Soil Mechanics and Foundation Engineering, Stockholm, Vol. 1, 721-724.

[9] TakiO.and Yang D.(1991), "Soil Cement Mixed Wall Technique", Geotechnical Engineering Congress, ASCE, New York, Special Publication, 27: 298-203.

[10] ÅhnbergH.(1996) "Stress dependent parameters of cement stabilized soil", Proceedings of the 2nd International Conference on Ground Improvement Geosystems, IS-Tokyo '96, Tokyo, 14-17 May, Vol. 1, pp. 387-392.

[11] UddinK.,Balasubramaniam A.S.and Bergado D.T. (1997), "Engineering Behaviour of CementTreated Bangkok Soft Clay", Geotechnical Engineering-SEA GS, Vol. 28, No. 1, 89-119.

[12] ÅhnbergH., S.Johansson, Phil H.and Carlsson T.(2003), "Stabilizing effects of different binders in some Swedish soils". Ground Improvement, Vol. 7, No. 1, pp. 9-23.

[13] Åhnberg H. (2006), "Strength of stabilised soils, A Laboratory Study on Clays and Organic Soils Stabilised with Different Types of Binder", Thesis Ph.D., Department of Construction Sciences, LTH, Lund University, Sweden.

[14] Başer O. (2009), "stabilization of expansive soils usingwaste marble dust" Thesis M.Sc.,
Department of Civil Engineering, Middle East Technical University.

[15] Wayne S.\&Adaska P. (2008), "Beneficial Uses of Cement Kiln Dust"IEEE/PCA 50th Cement Industry Technical Conf., Miami, FL, May 19-22.

[16] Mohamadien H. A. (2012), "The Effect of Marble Powder and Silica Fume as Partial Replacement for Cement on Mortar", International Journal of Civil \& Structural Engineering, Volu me 3, No 2.

[17] CDIT (2002), "The Deep Mixing Method, Principle, Design and Construction", Coastal Development Institute of Technology (CDIT), Japan.

[18] Jacobson (2005), "Factors Affecting Strength Gain in Lime-Cement Columns and Development of a Laboratory Testing Procedure", M.Sc. Thesis, Blacksburg, Virginia Tech.

[19] FilzG., HodgesD., WeatherbyD. and Marr W.(2005), "Standardized Definitions andLaboratory Procedures for Soil-Cement Specimens Applicable to the Wet Method of DeepMixing". Innovations in Grouting and Soil Improvement, Reston, Virginia.

[20] ECP 202/2 (1995), "Egyptian Code of Soil Mechanics and Foundation Engineering, $2^{\text {nd }}$ part, Laboratory Tests.

[21] Ibrahim O. (2012), "Properties Of Green Concrete Containing Different Materials As Replacement For Fine Aggregate", M.Sc., Thesis, Department of Civil Construction and Architecture - Suez Canal University

[22] JanzM.\& Johansson S.E. (2001), "The function of different binding agents in deep stabilization". Swedish Deep Stabilisation Research Centre, Report No. 9.

[23] ChewS., KamruzzamanA.H.M., \& LeeE.H., (2004), "Physicochemical and engineering behaviour of cement treated clays", Journal of Geotechnical and Geoenvironmental Engineering, Vol. 130, No. 7, July 1, 2004. pp. 696-706.

[24] Taylor, H.F.W. (1997),"Cement chemistry", $2^{\text {nd }}$ edition, Tho mas Telford, London 1997.

[25] ES 584/2003, "Quick lime and hydrated lime for building",Egyptian standards.

[26] EC 203/2007“"Egyptian Code for Design and construction of Concrete Structures", Ministry ofHousing, Utilities and New Urban Communities, Cairo, Egypt, (2007)

[27] ESS 1109/2002,Egyptian Standard Specifications "concrete aggregates from naturalsources"

[28] SaitohS., NishiokaS. M., SuzukiY., and Oku mara R. (1996), "Required strength of cement improved ground", Proceedings the $2^{\text {nd }}$ International Conference on Ground Improvement Geosystems, Grouting and Deep Mixing, 14-17 May, Tokyo, 1, 557-562.

[29] PorbahaA., ShibuyaS.and Kishida T. (2000) "State of the Art in Deep Mixing Technology", Ground Improvement, Vol. 4, No. 3, 91-110.

[30] EuroSoilStab (2002), "Development of design and construction methods to stabilize soft organic soils. Design guide soft soil stabilization", CT970351. Project No. BE-96-3177, Industrial \& 
Materials Technologies Programme (BriteEu Ram III), European Commission. Book035

[31] Moseley M.P. and Kirsch K. (2004), " Ground Improvement “, Second Edition, Spon Press2 Park Square, Milton Park, Abingdon, Oxon, OX14 4RN

[32] GreenM., and SmiganR.(1995), "Material properties and computer simulation of the behaviour of single columns", Final YearProject 95/11, Royal Institute of Technology, Stockholm.

[33] TerashiM., TanakaH., \& OkumuraT. (1979)," Engineering properties of lime-treated marine soils and D. M. Method", Proc. 6th Regional Conferenceon Soil Mechanics and Foundation Engineering. Singapore 1979, Vol.1, pp. 191-194.
[34] Lorenzo G., \& Bergado D.(2002),"Fundamental parameters of cementadmixed clay, New approach", Journal of Geotechnical andGeoenviron mental Engineering, Vol. 130, No. 10, pp. 1042-1050.

[35] Mamunul H. (2009), “Engineering Characteristics of Cement Stabilized Soft Finnish Clay - A Laboratory Study", Thesis, M.Sc., Department of Civil and Environmental Engineering Faculty of Engineering and Architecture, Helsinki University of Technology.

[36] Kamata H. \&Akutsu H.(1976), "Deep Mixing Method from Site Experience", Proceedings of the Journal of Japanese Society of Soil Mechanics and Engineering, Tsuchi to Kiso, 24 (12): 43:50. 